JURNAL SYNTAX FUSION

Vol 2 No 02, Februari 2022

E-ISSN: 2775-6440 | P-ISSN: 2808-7208

Jurnal Homepage https://fusion.rifainstitute.com

\title{
LITERATUR REVIEW: MATA KERING AKIBAT OBAT-OBATAN
}

\section{Nur Izzatush Sholihah}

Fakultas Kedokteran, Universitas Mataram, Indonesia.

Email: nurizzatush@gmail.com

\begin{abstract}
Abstrak
Penyakit mata kering adalah penyakit yang sering ditemui dan dapat terjadi akibat beberapa faktor. Penyakit ini lebih sering dialami oleh wanita daripada pria. Adapun faktor risiko yang dapat menyebabkan mata kering terbagi berdasarkan karakter individu, lingkungan, penyakit kronis, penyakti autoimun, obat-obatan dan riwayat cedera. Penulisan artikel ini didapatkan dari berbagai sumber berupa jurnal ilmiah dan pedoman bagi institusi terkait. Pencarian sumber dilakukan di berbagai portal online seperti Medscape, NCBI, Google Scholar dan website kesehatan lainnya dengan kata kunci "Dry Eye Disease", "Dry Eye Syndrome", "Medications Causes Dry Eyes" Penyakit mata kering merupakan penyakit yang sering dijumpai dan terjadi karena multifaktorial serta dapat memengaruhi kualitas hidup dan menganggu penglihatan terutama saat melakukan aktivitas sehari-hari. Salah satu faktor yang menyebabkan mata kering, yaitu penggunaan obat-obatan baik obat topikal maupun obat sistemik. Penggunaan lima atau lebih obat secara bersamaan dapat meningkatkan terjadinya mata kering. Tatalaksana mata kering dapat diberikan air mata buatan dan menghentikan penggunaan obat pencetus mata kering atau mengganti obat dengan obat lainnya. Penyakit mata kering dapat disebabkan oleh penggunaan obat-obatan, baik obat topikal maupun obat sistemik. Tatalaksana yang dapat dilakukan, yaitu dengan pemberian air mata buatan dan menghindari obat sistemik maupun obat mata topikal yang menyebabkan mata kering.
\end{abstract}

Kata Kunci: Penyakit mata kering, obat topikal, obat sistemik

\section{Abstract}

Dry eye disease is a disease that is often encountered and can occur due to several factors. This disease is more common in women than men. The risk factors that can cause dry eyes are divided based on individual characteristics, environment, chronic disease, autoimmune disease, medications and history of injury. The writing of this article was obtained from various sources in the form of scientific journals and guidelines for related institutions. Source searches were carried out on various online portals such as Medscape, NCBI, Google Scholar and other health websites with the keyword "Dry Eye Disease", "Dry Eye Syndrome", "Medications Causes Dry Eyes" Dry eye disease is a disease that is often encountered and occurs because it is multifactorial and can affect the quality of life and interfere with vision, especially when carrying out daily activities. One of the factors that cause dry eyes, namely the use of drugs, both topical drugs and systemic drugs.

Copyright holder: Nur Izzatush Sholihah (2022)

DOI : : https://doi.org/10.54543/fusion.v2i02.158

Published by : Rifa Institute 
Concurrent use of five or more medications can increase the occurrence of dry eye. Management of dry eyes can be given artificial tears and stop using medications that trigger dry eyes or replace the drug with another drug. Dry eye disease can be caused by the use of drugs, both topical and systemic drugs. Treatment that can be done, namely by giving artificial tears and avoiding systemic or topical ophthalmic drugs that cause dry eyes.

Keywords: Dry eye disease, topical medication, systemic medication

Diserahkan: 03-01-2022Ｄiterima: 25-01-2022Ｄiterbitkan: 20-02-2022

\section{Pendahuluan}

Penyakit mata kering atau yang dalam bahasa inggris disebut dry eyes disease atau dry eyes syndrome merupakan penyakit yang sering dijumpai dan terjadi karena penyebab multifaktorial. Mata kering dapat memengaruhi kualitas hidup dan menganggu penglihatan terutama saat melakukan aktivitas sehari-hari seperti, membaca, menulis maupun bekerja menggunakan monitor (Rouen and White, 2018). Epidemiologi dari mata kering di dunia yaitu diperkirakan sekitar 5\%-34\%, dimana prevalensi ini semakin meningkat secara signifikan berdasarkan usia (Messmer, 2015). Angka kejadian mata kering dijumpai sebanyak 3,2 juta pada wanita dan sebanyak 1,6 juta pada pria dengan usia lebih dari 50 tahun (Elvira \& Wijaya, 2018).

Penyakit ini dapat terjadi karena menurunnya cairan aqueous yang diproduksi oleh badan siliar atau meningkatnya evaporasi air mata yang terjadi akibat terganggunya fungsi kelenjar meibom. Berdasarkan penyebab tersebut mata kering dikelompokkan menjadi dua yaitu mata kering defisiensi aqeuos (MKDA) dan mata kering evaporasi (MKE) (Elvira \& Wijaya, 2018).

Faktor risiko terjadinya mata kering dapat dibagi berdasarkan karakter individu, lingkungan, penyakit kronis, penyakti autoimun, obat-obatan dan cedera. Untuk obatobatan yang dapat memengaruhi mata kering yaitu antihistamin H1, beta-bloker, dekongestan, diuretik, inhibitor reuptake serotonin selektif (SSRI), ansiolitik, antidepresan, antipsikotik, kontrasepsi oral, antiparkinson dan isotretinoin (Rouen \& White, 2018).

Sebanyak 62\% kasus mata kering pada usia lanjut terjadi karena obat sistemik salah satunya yaitu NSAID (Gomes et al., 2017). Pada penelitian lain prevalensi pasien mata kering yang mengkonsumsi antihistamin, diperkirakan sebanyak 22\% sedangkan yang tidak menggunakan antihistamin yaitu sebanyak 10\%. (Askeroglu et al, 2013).

\section{Metode Penelitian}

Penulisan artikel ini didapatkan dari berbagai sumber berupa jurnal ilmiah dan pedoman bagi institusi terkait. Pencarian sumber dilakukan di berbagai portal online seperti Medscape, Nation Center for Biotechnology Information/NCBI, Google Scholar dan website kesehatan lainnya dengan kata kunci "Dry Eye Disease”, "Dry Eye Syndrome", "Medications Causes Dry Eyes"

\section{Hasil dan Pembahasan}

\section{A. Definisi dan Epidemiologi}


Penyakit mata kering merupakan penyakit multifaktorial yang menyebabkan ketidaknyamanan pada mata, gangguan penglihatan, dan berpotensi menyebabkan kerusakan pada permukaan mata (Foster, 2019). Berdasarkan TFOS DEWS II mata kering merupakan penyakit yang terjadi akibat multifactorial yang terjadi pada permukaan ocular ditandai dengan hilangnya homeostasis lapisan air mata dan disertai dengan gejala okular, dimana gangguan homeostasis lapisan ait mata dan hiperosmolaritas, peradangan dan kerusakan permukaan okulat dan kelainan neurosensorik yang berperan dalam etiologi mata kering (Craig et al., 2017).

Prevalensi penyakit mata kering di Amerika Serikat sering terjadi pada pria, yaitu sebanyak 4,3\%. Sementara di Asia paling sering ditemui pada wanita, yaitu 21,6\%. Pada kawasan Asia Tenggara sebanyak 20\%-52,4\% masyarakat menderita penyakit mata kering (Uchino, 2018). Diperkirakan sekitar 6 juta penduduk di Amerika Serikat mengalami gejala mata kering namun tidak terdiagnosis sebagai penyakit mata kering. Prevalensi pada Wanita lebih banyak dibandingkan laki-laki dan kejadian mata kering akan meningkat seiring dengan bertambahnya usia. Pada satu penelitian yang berbasi populasi disebutkan bahwa prevalensi mata kering pada wanita berusia 50 tahun keatas yaitu 11,3\% dan pada usia 75 tahun keatas yaitu 22,8\% (O’Neil et al., 2019).

\section{B. Patofisologi}

Faktor risiko terjadinya mata kering dapat dikarenakan berbagai faktor salah satunya yaitu akibat penggunaan obat-obatan baik obat topikal maupun obat sistemik (Askeroglu et al., 2013). Penggunaan lima atau lebih obat secara bersamaan atau politerapi dapat meningkatkan terjadinya mata kering (Gomes et al., 2017). Mekanisme terjadinya mata kering berdasarkan obat yang digunakan yaitu:

\section{a. Obat sistemik}

Secara umum, obat sistemik dapat menyebabkan mata kering sekunder karena penurunan produksi air mata, perubahan input saraf termasuk refleks sekresi dan penurunan sensasi kornea atau efek inflamasi langsung pada kelenjar sekretori (Fraunfelder et al., 2012; Gomes et al., 2017). Obat sistemik yang memberikan efek berupa mata kering, biasanya merupakan obat dengan aktivitas antimuskarinik. Obat antimuskarinik terdiri dari berbagai kategori obat termasuk antidepresan, antipsikotik atau neuroleptik, anti-Parkinson, antihistamin $\mathrm{H} 1$, dekongestan dan antispasmodik. Obat antimuskarinik sistemik dapat memengaruhi reseptor muskarinik yang berikatan dengan protein $G$ di kelenjar lakrimal dan sel epitel penghasil mucus sehingga mengurangi produksi komponen air mata dan mucus, dan mengurangi stabilitas lapisan air mata yang dihasilkan (Gomes et al., 2017). Pada penggunaan antihistamin $\mathrm{H}$, efek samping yang terjadi berupa kekeringan pada mukosa mulut dan pernapasan, penurunan keluaran aqueous dari kelenjar lakrimal dan keluaran musin dari sel goblet (Askeroglu et al., 2013). Obat-obatan sistemik dengan efek samping berupa mulut kering, disebutkan berhubungan dengan terjadinya mata kering (Fraunfelder et al, 2012).

Mekanisme mata kering akibat obat golongan adrenergik, termasuk betablocker dan agonis alfa dapat menimbulkan perubahan dalam produksi air mata dan kualitas tear film. Hal tersebut terjadi karena mediasi oleh produksi protein kinase C dan konsentrasi Ca++ intraseluler (Gomes et al., 2017). Beta-blocker akan menurunkan produksi aquos dengan mengurangi kadar lisozim dan imunoglobulin 
Nur Izzatush Sholihah

A. Beta-blocker juga menyebabkan penurunan waktu pemecahan tear film mata, dan iritasi mata. (Askeroglu et al., 2013).

\section{a. Obat topikal}

Mekanisme obat topikal dalam menyebabkan mata kering sedikit berbeda dari obat sistemik. Kejadian mata kering pada penggunaan obat topikal dapat disebabkan oleh konsentrasi obat yang biasanya lebih tinggi, frekuensi aplikasi yang lebih sering, efek dari kandungan pengawet pada obat, terapi jangka panjang dan peradangan permukaan mata yang diinduksi obat. Obat topikal dapat menyebabkan perubahan lapisan air mata yang menyebabkan peningkatan penguapan dan peradangan jaringan mata, termasuk uveitis dan skleritis. Mekanisme yang memungkinkan terjadi pada mata kering karena obat topikal yaitu dapat mengganggu sel goblet, kelenjar meibom, permukaan okular konjungtiva dan kornea, dan sifat lapisan air (Fraunfelder et al, 2012).

Penggunaan pengawet pada obat topikal berupa benzalkonium chloride juga dapat menganggu sel goblet dalam menghasilkan musin. yang berkontribusi pada stabilitas lapisan air mata dan memiliki sifat prokteftif. Akibat sifat toksik dari benzalkonium chloride maka dapat menghilangkan sifat protektif sel musin sehingga lapisan air mata yang rusak tidak hanya menyebabkan gejala mata kering dan kerusakan kornea, tetapi juga dapat membawa mediator inflamasi sitotoksik ke seluruh permukaan mata. Perubahan lapisan air mata dapat merangsang serangkaian perubahan biologis pada permukaan mata, yang menyebabkan peradangan neurogenik dan kerusakan lapisan air mata lebih lanjut (Gomes et al., 2017)

\section{Manifestasi Klinis dan Diagnosis}

Untuk menentukan diagnosis mata kering dapat dimulai dengan anamnesis mengenai gejala dan tanda, riwayat tindakan operasi mata, riwayat penggunaan obatobatan, serta penyakit lainnya (Elvira \& Wijaya, 2018). Selain itu juga perlu diketahui mengenai penggunaan Visual Display Unit, kondisi lingkungan berupa udara kering atau berdebu, penggunaan Air Conditioner, dan penyakit sistemik (seperti penyakit vaskular kolagen, penyakit Graves, diabetes mellitus, infeksi seperti hepatitis C dan HIV) (Messmer, 2015).

Gejala yang dapat ditemukan dari mata kering biasanya berupa kemerahan, terasa terbakar, menyengat, seperti ada benda asing, pruritus, penglihatan kabur dan foto fobia. Kemerahan konjungtiva dan kerusakan pada permukaan okular dengan erosi epitel pungtata (keratitis pungtata superfisial) adalah gejala yang umum pada mata kering (Messmer, 2015)

Pemeriksaan yang dapat dilakukan untuk mendiagnosis mata kering dapat menggunakan Tear film break-up time (TBUT) dengan fluorescein. TBUT adalah periode yang dibutuhkan oleh tear film untuk pecah mengikuti kedipan mata, normalnya yaitu 1520 detik. Pada kondisi mata kering, waktu TBUT, yaitu 5-10 detik. Kemudian dilakukan pemeriksaan pewarnaan pada permukaan mata menggunakan fluoresein atau lissamine green, tes Schirmer I dengan atau tanpa anestesi/ tes Schirmer II dengan stimulasi nasal, pemeriksaan kelopak mata serta kelenjar meibom. Tes Schirmer I berfungsi untuk menilai jumlah produksi air mata oleh kelenjar lakrimal. Sedangkan pewarnaan permukaan mata menggunakan fluoresein berfungsi untuk menilai derajat keparahan dari epitel kornea (Elvira \& Wijaya, 2018) 
Untuk membedakan antara MKDA dan MKE, dapat dinilai dengan berkurangnya meniskus air mata, adanya LIPCOFs (lid-parallel conjunctival folds), dan hasil tes Schirmer I yang rendah pada MKDA. Sedangkan pada MKE biasanya menunjukkan perubahan patologis pada tepi kelopak mata, obstruksi lubang kelenjar meibom, dan sekresi kelenjar meibom yang menebal. (Messmer, 2015).

\section{Tatalaksana}

Mata kering terjadi akibat gangguan pada tear film baik pada lapisan mucin, aqueous, dan lipid. Dalam memilih terapi yang dapat diberikan disesuaikan berdasarkan etiologinya. Penggunaan obat-obat topical pada mata sebaiknya bebas zat pengawet, hipotonik, atau isotonik, dan mengandung elektrolit, $\mathrm{pH}$ netral atau sedikit basa, dan osmolaritas 181-354 mOsm/L. Tatalaksana secara umum yang dapat diberikan berupa pemberian air mata buatan yaitu metakarboksilmetilselulosa atau sodium hialuronat (Elvira \& Wijaya, 2018).

Selain itu, dapat dilakukan retensi air mata dengan indikasi tes Schirmer $<5 \mathrm{~mm}$ dan pewarnaan positif pada permukaan okular. Tatalaksana lainnya adalah mengobati radang pada kelopak mata dengan kompres air hangat pada kelopak mata atau memberikan doksisiklin dan tetrasiklin oral (Rathi dan Virender, 2017).

Pada penderita mata kering akibat obat dapat dilakukan dengan mengidentifikasi obat sistemik maupun topikal yang menyebabkan mata kering. Apabila memungkinkan, obat yang digunakan dapat diubah dengan obat alternatif lain yang memiliki mekanisme kerja tanpa menimbulkan efek samping pada mata. Pada penggunaan obat topikal, frekuensi pemberiannya dapat dikurangi untuk mencegah mata kering. Apabila akan menggunakan tetes mata untuk mengobati mata kering, gunakan tetes mata yang bebas bahan pengawet (Gomes et al., 2017).

\section{E. Komplikasi}

Penyakit mata kering dapat menyebabkan infeksi pada mata, rusaknya permukaan mata seperti abrasi kornea, dan penurunan kualitas hidup (Mayoclinic, 2020). Mata kering yang sudah parah dapat menimbulkan jaringan parut pada konjungtiva, keratitis filamen, kerusakan epitel persisten, dan perforasi kornea. Komplikasi lain mata kering dapat berupa kehilangan penglihatan yang dikaitkan dengan sindrom Sjögren, penyakit graft versus host, ichthyosis, sindrom Stevens Johnson, dan xerophthalmia (x14-x21) (Messmer, 2015).

\section{Kesimpulan}

Penyakit mata kering dapat disebabkan oleh beberapa faktor. Salah satu faktor penyebabnya, yaitu penggunaan obat-obatan, baik obat topikal maupun obat sistemik. Mata kering karena obat sistemik terjadi karena penurunan produksi air mata, perubahan input saraf termasuk refleks sekresi dan penurunan sensasi kornea atau efek inflamasi langsung pada kelenjar sekretori. Obat sistemik yang dapat menyebabkan mata merah salah satunya yaitu obat antimuskarini. Obat topikal dapat menyebabkan mata kering karena konsentrasi obat yang lebih tinggi, frekuensi aplikasi yang lebih sering, kandungan pengawet pada obat, terapi jangka panjang dan peradangan permukaan mata yang diinduksi obat Tatalaksana secara umum dapat diberikan air mata buatan. Tatalaksana lainnya yaitu dengan menghentikan penggunaan obat yang menyebabkan mata kering atau menggati obat dengan obat lainnya dan menghindari penggunaan obat mata yang mengangung benzalkonium chloride. 
Nur Izzatush Sholihah

\section{BIBLIOGRAFI}

Askeroglu, U., Alleyne, B., \& Guyuron, B. (2013). Pharmaceutical and herbal products that may contribute to dry eyes. Plastic and Reconstructive Surgery, 131(1), 159-167. Google Scholar

Craig, J. P., Nichols, K. K., Akpek, E. K., Caffery, B., Dua, H. S., Joo, C. K., ... \& Stapleton, F. (2017). TFOS DEWS II definition and classification report. The ocular surface, 15(3), 276-283. Google Scholar

Elvira, \& Wijaya, V. N. (2018). Penyakit Mata Kering. CDK Edisi Suplemen, 192-196. Google Scholar

Foster, C. S. (2019). Dry Eye Disease (Keratoconjunctivitis Sicca). Google Scholar

Fraunfelder, F. T., Sciubba, J. J., \& Mathers, W. D. (2012). The Role of Medications in Causing Dry Eye. Journal of Ophthalmology, 2012(August). Google Scholar

Gomes, J. A. P., Azar, D. T., Baudouin, C., Efron, N., Hirayama, M., Horwath-Winter, J., ... Wolffsohn, J. S. (2017). TFOS DEWS II iatrogenic report. Ocular Surface, 15(3), 511-538. Google Scholar

Mayoclinic. (2020). Dry Eyes. https://www.mayoclinic.org/diseases-conditions/dryeyes/symptoms-causes/syc-20371863 Google Scholar

Messmer, E. M. (2015). Pathophysiology, diagnosis and treatment of dry eye. Deutsches Arzteblatt International, 112(5), 71-82. https://doi.org/10.3238/arztebl.2015.0071 Google Scholar

O’Neil, E. C., Henderson, M., Massaro-Giordano, M., \& Bunya, V. Y. (2019). Advances in dry eye disease treatment. Current opinion in ophthalmology, 30(3), 166. Google Scholar

Rathi, V. M., \& Sangwan, V. S. (2017). Prevention, diagnosis \& management of dry eye in South Asia. Community eye health, 30(99),S3-S4. Google Scholar

Rouen, P. A., \& White, M. L. (2018). Dry Eye Disease: Prevalence, Assessment, and Management. Home Healthcare Now, 36(2). Retrieved from https://journals.lww.com/homehealthcarenurseonline/Fulltext/2018/03000/Dry_Eye_D isease_Prevalence,_Assessment,_and.3.aspx Google Scholar

Uchino, M. (2018). What We Know About the Epidemiology of Dry Eye Disease in Japan. Investigative Ophthalmology \& Visual Science November 2018, Vol.59, DES1-DES6. doi:https://doi.org/10.1167/iovs.17-23491 Google Scholar

First publication right:

Jurnal Syntax Fusion: Jurnal Nasional Indonesia

This article is licensed under:

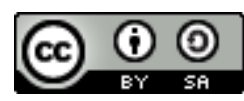

